WORKING PAPER

THE STRUGGLE AGAINST CREATIVE ACCOUNTING: IS "TRUE AND FAIR VIEW" PART OF THE PROBLEM OR PART OF THE SOLUTION?

Oriol Amat, John Blake and Ester Oliveras 


\title{
THE STRUGGLE AGAINST CREATIVE ACCOUNTING: IS "TRUE AND FAIR VIEW" PART OF THE PROBLEM OR PART OF THE SOLUTION?
}

\begin{abstract}
Creative accounting is a growing issue of interest in Spain. In this article we argue that the concept true and fair view can limit or promote the use of creative accounting depending upon its interpretation. We review the range of meanings that true and fair view can take at an international level and compare the experience of the United Kingdom with the Australian one by analysing the use of true and fair view to limit creative accounting. Finally, we suggest lines of action to be considered by the Spanish accounting standards-setting institutions.
\end{abstract}

Key words: creative accounting, imagen fiel, true and fair view, accounting regulation 


\section{THE STRUGGLE AGAINST CREATIVE ACCOUNTING: IS "TRUE AND FAIR VIEW" PART OF THE PROBLEM OR PART OF THE SOLUTION?}

\section{Introduction}

Creative accounting is a growing issue of concern in Spain, threatening the credibility of both the accounting and auditing functions. In this paper we:

1) Explore the nature of creative accounting.

2) Consider how accounting regulations can be formulated to combat creative accounting.

3) Review the range of meaning that can be attached to the term true and fair view in the United Kingdom.

4) Compare the experience of the UK with that of Australia in the relationship between the use of the objective true and fair view to contend creative accounting.

5) Offer suggestions as to how Spain may take advantage of this experience by using accounting regulation in order to improve the satisfaction of the needs that accounting tries to meet.

\section{The nature of creative accounting}

There are several definitions for creative accounting. For example, Naser (1993) from an academic point of view, offers the following definition:

"Creative accounting may be defined as:

- the process of manipulating accounting figures by taking advantage of the loopholes in accounting rules and the choices of measurement and disclosure practices in them to transform financial statements from what they should be, to what preparers would prefer to see reported, and

the process by which transactions are structured so as to produce the required accounting results rather than reporting transactions in a neutral and consistent way" (p. 59)

If we explore this definition we find that some interesting assertions are implied. By saying that creative accounting transforms accounts from what they 'should' be it is implied that there 
is some absolute truth in accounting that could be achieved if only the rules were applied impartially. Similarly there is a reference to an idea that transactions should be reported in a 'neutral and consistent' way, the term neutral again implying a need for impartiality.

Most commentators view creative accounting with distate. In this line, Griffiths (1985) or Jameson (1988) who indicates:

"Let there be no doubt about it, creative accounting is a bad thing. It distorts company results and financial position and, if the theorists are to be believed is likely to become increasingly common" (p. 20).

Smith (1992) illustrates his contention that creative accounting is a serious problem with case studies of three UK listed companies, which collapsed shortly after presenting accounts that seemed to indicate financial strength. The author argues:

"These three large corporate collapses all owe their occurrence in some respects to techniques of creative accounting or financial engineering" (p. 9).

In a study carried out by Leung and Cooper (1995) to 1.500 accountants in Australia, highlighted that creative accounting is considered one of the major ethical problems of the accounting profession. Table 1 shows that $50,1 \%$ of respondants stated that the problems of manipulation $\mathrm{n}$ of financial information by clients, presented an ethical problem for accounting professionals. 
Table 1. Most frequently cited ethical problems in Australia

\begin{tabular}{|l|c|}
\hline & \% of respondents \\
\hline Conflict of interest & 51,9 \\
\hline Client proposal to manipulate accounts & 50,1 \\
\hline Client proposal for tax evasion & 46,8 \\
\hline
\end{tabular}

Source: Leung and Cooper (1995)

In the Spanish context, there also exist a critical vision of creative accounting. For example, according to Rojo (1993) creative accounting is "a system of accounting shaped for and by the needs of a company's image" and "is caused by short term speculative thinking".

The incidence of creative accounting is particularly strong in the United Kingdom compared with:

- The countries of continental Europe such as France, Germany or Spain where the roman law tradition applies and accounting rules do not allow the flexibility that enables accountants to make choices that favour them.

- The USA, where a common law tradition applies as in the UK, but the high risk and cost of litigation have led the accounting profession to formulate agreed, highly detailed procedures that can be justified in court. By contrast, litigation risk is much lower in the UK.

As an example, in Table 2 there is a summary of two studies by Naser (1993) and Amat and Blake (1996) in which the attitudes of auditors in respect the usage of creative accounting were investigated. According to these studies, few auditors consider the use of creative accounting as a legitimate business tool. Also interesting, is the contrast between both countries, $91 \%$ of respondants from the United Kingdom assert that the problem of creative accounting can never be solved, while in Spain this percentage is only $38 \%$ of the respondants. 
Table 2. Summary of results of surveys of auditor's attitudes to creative accounting

\begin{tabular}{|lcc|}
\hline Agreement with the proposition & United Kingdom (\%) & Spain (\%) \\
$\begin{array}{l}\text { The use of creative accounting is a legitimate } \\
\text { business tool }\end{array}$ & 36 & 31 \\
$\begin{array}{l}\text { Creative accounting is a problem that can never be } \\
\text { solved }\end{array}$ & 91 & 38 \\
\hline
\end{tabular}

Source: Taken from Naser (1993) and Amat and Blake (1996)

In despite of these figures, recent British accounting rules i.e. the Financial Reporting Standards (FRS) are being designed in a way that limits the use of creative accounting. But, this will be analysed in the next section.

\section{Drafting regulations to combat creative accounting}

Accounting regulators who wish to limit the opportunities in which creative accounting can be used could consider the possibility of approaching separately the diverse situations that allow the application of creative accounting:

1) A first step towards the reduction of possibilities to use creative accounting consists in the continuous development of a conceptual framework in the line of work carried out by AECA (Cañibano, 1992 p. 115). In this way, the objectives of financial information will be clarified and priorities clearly established. In this way, Gabás (1991) observes:

\footnotetext{
"The orientations to design accounting rules have a double function, firstly they affect accounting standards-setters but they also establish general criteria which are useful to professionals in that they allow a more profound understanding of accounting legislation, which facilitates the analysis of complex cases and lay the foundations of a professional opinion about accounting practices" (p. 19)
}

2) In the field of election of an accounting method over another creative accounting could be reduced by reducing the allowed accounting criteria or clearly specifying the circumstance in which a method should be applied. It can also help to require uniformity in the use of accounting methods. Nowadays, in Spain the accounting criteria can be 
changed if it is explained in the Annual accounts' report and the impact of this change is quantified in the result of the company. If the change of criteria is forbidden, when a company chooses a criteria, because with it achieves the image that is needed for that financial year, the same criteria will have to be used in future circumstances.

3) The potential abuse of financial directors using their own opinions could be moderated by using two methods. The first method consists in designing accounting norms which minimise the use of subjective opinions. For example, accountants in the United Kingdom tended to use the extraordinary section in the profit and loss account to include accounts avoiding its inclusion in the ordinary profit. The Accounting Standards Board (ASB) in the United Kingdom responded by abolishing the category of extraordinary accounts.

The second method is that auditors must intensify their role in the identification of dishonest estimates. When completing auditing reports, these professionals must evaluate if there have been accounting manipulations of the annual accounts. In this area, it is worth mentioning the existing debate around the responsibilities assigned to the auditing function. Audit expectations gap, is the concept used to describe the difference between what is expected from auditors and what is actually established in current legislation. Benau and Humphrey (1995) propose that the auditing function should include the evaluation of internal control systems of the company to identify in a preventive manner the cases of creative accounting, or in extreme cases of fraud (p. 714).

4) Artificial transactions can be treated by invoking the concept of "substance over form", by which is the economic substance and not the legal form of the transaction what determines the accounting substance. For example, linked transactions would be accounted as a whole.

5) The direction of the company decides in which moment extraordinary transactions of fixed assets should take place. In any case, the scope of its use could be limited by requiring regular valuations of fixed assets, in this way the profits or losses for changes of value would be identified in the annual accounts every year, when they are actually produced rather than to appear only the year that the asset is sold.

As it has been indicated, creative accounting is perceived as a characteristic of the Anglo- 
Saxon approach to accounting, very flexible and with scope for different opinions, much more than the continental European model, which traditionally is more rigid and with detailed accounting norms. In any case, as shown in Table 3 both approaches have potential for the reduction of the possibilities to control creative accounting. The continental European model facilitates the reduction of the possibilities to abuse the election of an accounting policy and the manipulation of accounting estimates. The Anglo-Saxon model drives towards the use of 'substance over form' and revaluations.

Table 3. Opportunities for creative accounting

\begin{tabular}{|l|l|l|}
\hline $\begin{array}{l}\text { Opportunity for creative } \\
\text { accounting }\end{array}$ & $\begin{array}{l}\text { Solution available to } \\
\text { accounting regulator }\end{array}$ & $\begin{array}{l}\text { Accounting tradition } \\
\text { where solution is most } \\
\text { easily applied }\end{array}$ \\
\hline $\begin{array}{l}\text { Choice of accounting } \\
\text { method }\end{array}$ & Reduce permitted choice & Continental European \\
\hline $\begin{array}{l}\text { Bias estimates and } \\
\text { prediction }\end{array}$ & Reduce scope for estimate & Continental European \\
\hline $\begin{array}{l}\text { Enter into artificial } \\
\text { transactions }\end{array}$ & Substance over form & Anglo-Saxon \\
\hline $\begin{array}{l}\text { Timing of genuine } \\
\text { transactions }\end{array}$ & Prescribe revaluation & Anglo-Saxon \\
\hline
\end{tabular}

\section{The concept of true and fair view from a UK perspective}

The term "true and fair view" was introduced in British legislation in the 1948 Companies Act. Curiously, this law did not include a definition of what was understood by true and fair view. Furthermore, posterior legislation has not offered a definition of this expression.

The difficulty of defining the concept of true and fair view was illustrated in 1992 when three of the UK's leading accountants were asked to define the term on a television programme. None of them accepted the challenge ( Accountancy Age on $19^{\text {th }}$ March 1992).

One of the few existing definitions offered has been by Lee (1981):

"Today, 'true and fair view' has become a term of art. It is generally understood to mean a presentation of accounts, drawn up according to accepted accounting principles, using accurate figures as far as possible, and reasonable estimates 
otherwise; and arranging them so as to show, within the limits of current accounting practice, as objective a picture as possible, free from wilful bias, distortion, manipulation, or concealment of material facts. In other words, the spirit as well as the letter, of the law must be observed" (p. 270).

Four distinct, and to some extent conflicting, aspects of this definition can be seen:

1. References to "reasonable estimates" and "within the limits of current accounting practice" imply a tolerance of some unavoidable imprecision. In this respect, the "true and fair" requirement is contrasted with the "true and correct" requirement of the previous legislation. The change was recommended by the Institute of Chartered Accountants in England and Wales because.

\begin{abstract}
"The word 'correct' has always been too strong because it implies that there is one view which is 'correct' as against all others which are incorrect. In published accounts there is no standard of absolute truth and the Institute's suggested amendment would recognise that the presentation of figures can only be that which is, in the personal view of the auditor, a fair view" (see The Accountant, $1^{\text {st }}$ July 1944, p. 2).
\end{abstract}

In this aspect it could be considered as an incitement to creative accounting, because it increases flexibility.

2. To others the true and fair requirement has appeared as more rigorous than its predecessor. In this sense, Lord Benson (1989) argues:

"In effect substance took precedence over form" (p. 45).

Lee's definition above ties in with this view in referring to "concealment of material facts" and that "the spirit as well as the letter of the law". Some authorities see true as meaning the letter (the form) of the law, and fair the spirit. Cowan (1965) tells a story to contrast the two words. A ship's captain was concerned that the mate drank heavily. One day he made an entry in the ship's log: 
"The mate was drunk today".

This statement was both true and fair.

The following day the mate was on watch. He was angry at the entry about him in the log, and made his own entry:

"The captain was sober today"

This entry was true but, in its implication that the matter was so unusual as to be worthy of comment, was not fair. This aspect is a tool against creative accounting.

3. Lee refers to "as objective a picture as possible, free from wilful bias." The idea that accounts should possess the quality of "neutrality" or "freedom from bias" is well established (see Blake \& Higson 1992 for a full discussion). The two key elements of the concept are:

- The accounts should not claim to manipulate users to a particular conclusion. This aspect works against creative accounting.

- All segments of the user community should be well served the accounts..

1. Lee refers to "accounts drawn up according to accepted accounting principles". In the U.K. the one decided civil law case revolving around the issue of the true and fair view was Re Press caps Ltd. (1949, Ch. 434). In that case a shareholder challenged a Balance Sheet that showed a Freehold property valued at $£ 90,000$ at cost less depreciation of $£ 30,000$. Lord Justice Somervell upheld the accounting treatment on the grounds that it was "in accordance with what is very common practice". This judgement has been cited in support of the argument that a true and fair view can be achieved by following normal accounting practices. However, Williams (1985) points out that the other two judges in the Court of Appeal while coming down on the same side, did so on different grounds.

This view support the idea that "true and fair view" can be achieved by following the normal practice of accountants: 
"If a court ever had to decide whether a set of accounts gave a true and fair view it is difficult to see what other criteria could be applied other than whether the accounts are drawn up in accordance with the considered practice of accountants generally" (Mayson et al., 1989, p. 218).

\section{The international dimension}

Following the introduction of the "true and fair" view requirement in the 1947 Companies Act, the term was adopted for other countries, such as Australia, Hong Kong, Malaysia, New Zealand and Singapore.

Zeff (1972) affirms that New Zealand preferred to copy, in the 1955 Company Act, British law so that they could have as a guide the legal British precedents. Since 1970 most academic literature trying to define true and fair view comes from Australia and New Zealand. In any case, in these countries the problem of defining the term is also encountered. In that sense, Ryan (1967) observes:

"I would not for one moment contemplate a prosecution based on so slippery a concept as truth and fairness" (p. 107).

In 1973 the United Kingdom entered the European Community. By then, there was a first draft of the Directive which would harmonise company legislation. This draft was highly influenced by the German tradition with a legalistic approach to accounting regulation, leaving little room for interpretations from the accounting profession. As a response to the active representation of the British government, the draft was changed to include three key aspects:

1. Annual accounts must show a true and fair view.

2. When the application of the Fourth European Directive is not sufficient to show a true and fair view, additional information must be given to reflect a true and fair view.

3. If, in exceptional cases, the application of a specific principle from the directive (implemented through national legislation), a true and fair view is not achieved, that principles should not be applied, explaining the reasons for the override in the notes to the accounts. This is the prevalence of true and fair view over other accounting 
principles.

Tweedie (1983) explains the British motivation to include the term true and fair view in the Fourth Directive:

\begin{abstract}
"With the entry of the UK and Ireland in the EEC, the draft directive underwent a major change with the introduction of both the concept of the true and fair view and greater flexibility in presentation. Without these major amendments, financial reporting in the UK would have undergone fundamental changes in both philosophy and style" (p. 112).
\end{abstract}

In its practical application, these principles have had a different impact in each country from the European Community for several reasons:

1. Differences in the adoption of the Fourth Directive to national legislation:

Even though all countries have implemented the two first requirements exposed previously, Germany, Sweden and Portugal have not legislated for a true and fair view override. On the other side, Spain has left very clear the priority of the true and fair view objective, but this will be explained in another section. Some governments have pointed out that true and fair view has a minor priority. As an example, the official explanation to the German law implementing the true and fair view requirement: "In spite of the pretentious formulation it is supposed that for practice there will be no principle changes. As to now, the content and scope of the general clause will not be changed compared to the existing law" (Busse von Colbe, 1984, p. 124).

2. Differences in the translation of true and fair view:

Alexander (1993) explains that although true and fair view has British origins, the term expressed in each official language from the European Community has validity. According to the Fourth Directive, the expression true and fair view "is of compulsory use" (Navarro, 1996, p. 165). Rutherford (1983) studied the terms used in several countries and found interesting variations and emphasis in the translations. In particular, some countries translate the expression to a single word, losing the distinction between the two different, and 
potentially conflicting qualities. Nobes (1993, p. 39) contrasts the different meanings that true and fair view can have in several European countries:

Real (Greece)

Faithful (France, Belgium, Netherlands, Spain and Luxembourg)

Right-looking y according to facts (Denmark)

True and correct (Italy)

True and appropriate (Portugal)

True and fair (United Kingdom and Ireland)

3. Influence from previous national legislation:

Previous legislation tends to influence the interpretation of true and fair view. For example, in the United Kingdom it has mean the comparison with the previous requirement of true and correct. Likewise in France, the equivalent of image fidele is interpreted according to the previous requirement and still present of regularité et sincerité (Burlaud, 1993).

4. Influence in current practice:

From the moment in which the concept of true and fair view depends upon the current practice of accountants, both legislation and accounting practice vary amongst different countries.

Ordelheide (1993) offers a German perspective when arguing that in the context of the Fourth European Directive a "European principle of true and fair view" has emerged, which must be interpreted in the legal framework of the European Union and finally interpreted by the European Tribunal. In this sense, the author argues:

"It might well be that... Great Britain gets back its 'Trojan Horse', but now filled with a legalistic system instead of a professional one, with the addition of being characterised by the more prudent accounting of the Continent" (p. 83).

\section{Impact of true and fair view in the United Kingdom}


The term was originally brought into UK legislation via the Companies Act of 1947, which required every company to produce annually a balance sheet and profit and loss account showing a true and fair view of the state of its affairs, and further required that the company's auditors should report upon whether or not the accounts give a true and fair view.

The requirements remained unchanged in the consolidating Companies Act of 1948, and continued in exactly the same form until the 1981 Companies Act. In that year the requirement was refined by the inclusion of an "override" provision. The Act expressly state that its requirements "... as to the matters to be included in a company's accounts or in notes to those accounts" should be overridden where necessary in order to give a true and fair view. The purpose and priority of the legislation seems clear: detailed rules may be sacrificed to the overriding principle of true and fair.

Over the period between 1970 and 1981 the accounting profession added to prescriptive accounting regulation by producing standards, a process which has accelerated further during the 80s and 90s. Companies legislation now co-exists with a substantial body of professional guidance. The relationship between accounting standards and the law has become closer, to the point where adherence to the standards may be assumed in most circumstances to result in a "true and fair view" with particular reference to accounting standards. The ASC was motivated in doing so by a need to establish the status of accounting standards, and by the absence, referred to earlier, of case law which would define "true and fair" or lend support to the role of accounting standards in achieving truth and fairness in financial statements. The Joint Opinions of counsel at that time were that:

"the courts will treat compliance with accepted accounting standards as prima facie evidence that the accounts are true and fair".

The status of accounting standards was strengthened further still in the Companies Act 1989. Whilst not expressly stating that companies must as a statutory requirement comply with standards, the Act clearly implies that accounts should be prepared in accordance with them. A new section was added to the Companies Act 1985 as follows:

"It shall be stated whether the accounts have been prepared in accordance with applicable accounting standards and particulars of any material departure from those 
standards and the reasons for it shall be given".

The 1989 Companies Act formally recognises accounting standards, and provides that the Secretary of State may provide grants to fund the standard setting and compliance processes. In order to further define the alteration to the legal status of accounting standards the Accounting Standards Board (ASB) obtained the opinion of Mrs Justice Arden (ASB 1993). Her view was that the implications of the various relevant amendments to company law:

"increase the likelihood, to which the earlier Joint Opinion refer, that the Courts will hold that in general compliance with accounting standards is necessary to meet the true and fair view requirement".

The relationship between accounting standards compliance and the true and fair view has, then, grown closer during the recent period of the UK company law development. The UK standard setting bodies (the ASC until 1989, replaced by the Accounting Standards Board ASB) have developed their standards within the cultural tradition of the true and fair view, and have thus tended to strengthen and to help define the concept within a national context. Arden and Hoffman in their 1983 opinion touched on the question of the significance of the term:

"The meaning of true and fair remains what it was in 1947. It is the content given to the concept which has changed... the concept of a true and fair view is dynamic"

The development and fluid interpretation of the concept is illustrated by several cases of the true and fair override in action.

The first example which we consider is the case of Statement of Standard Accounting Practice (SSAP) No. 19, "Accounting for Investment Properties" issued by the ASC in 1981. An earlier Standard, SSAP 12 "Accounting for Depreciation" required that freehold and leasehold properties should be subject to depreciation, but excluded investments properties from its scope.

Investment properties as defined by SSAP 19 are not subject to depreciation, and are required to be shown in the balance sheet at open market value. The required accounting treatment in respect of depreciation is, however, in contravention of the Companies Act requirement (para. 
18 of Schedule 4 to the 1985 Companies Act) that the cost of "... any fixed asset which has a limited useful economic life ... shall be reduced by provisions for depreciation calculated to write off that amount systematically over the period of the asset's useful economic life." SSAP 19 recognises the conflict with the legal requirement but justifies it by invoking the true and fair override. The use of the override in this case could be interpreted as a somewhat arrogant assumption of the right to alter statute law by a interest group without statutory authority. An alternative interpretation is to view the episode in the positive light of the Hoffman and Arden opinion as an illustration of how the factual content given to the concept of true and fair changes over time.

A second, more recent, example shows how the standard setting body, now the ASB, continues to invoke the true and fair view override. The ASB has recently made attempts to deal with the controversial and perennially intractable problem of accounting for goodwill. One of the proposals in the Board's latest paper on the subject (ASB 1995) is that purchased goodwill which has an indefinitely long life may be retained in the balance sheet without necessarily being reduced by periodic charges of amortisation. The Companies Act 1985, however, requires that: ".. the amount of the consideration for any goodwill acquired by the company shall be reduced by provisions for depreciation calculated to write off that amount systematically over a period chosen by the directors of the company". And: "the period chosen shall not exceed the useful economic life of the goodwill in question." The ASB recognises that there is a conflict with the law, and, to counter the problem, intends that where goodwill was not to be depreciated the true and fair view override would need to be invoked.

The two cases quoted above illustrate a similar point, but the instances are separated by several years and the amendments in the 1989 Companies Act. The 1995 case perhaps presents less of a problem to the ASB than did the similar SSAP19 case to the ASC because of the additional authority acquired by the standard setting body in the intervening period. The ASB under the chairmanship of Sir David Tweedie, has seized the opportunity to interpret the true and fair requirement in the "progressive" mode which he identified several years ago (Tweedie, 1988):

"In its progressive form it can be used to replace antiquated laws and indeed outdated accounting standards prior to their revision." 
Although, referring to the second case quoted above, neither SSAP 22 "Accounting for Goodwill" - issued in 1984 - nor the 1985 Companies Act could perhaps genuinely be regarded as "antiquated".

Alexander (1993) is critical of the logical process which underlies the apparently casual alteration of the law in such circumstances. However, an examination of the amendments to the 1989 Companies Acts as interpreted by Arden certainly appears to support the progressive approach to national interpretations of the true and fair view which is currently being adopted in the UK. A rare dissenting voice to this view in the UK comes from Waller (1990) who argues the case for replacing true and fair view with a more legalistic and prescriptive approach, in order to combat creative accounting.

\section{Impact of true and fair view in Australia}

From 1995 onwards the Australian states, starting with Victoria, introduced the True and Fair View requirement into their company law. This followed an established tradition- for example, in 1896 Victoria departed from U.K. accounting practice in the Companies Act but returned to the U.K. practice in 1910, apparently to appeal to U.K. investors (Gibson, 1971).

In 1983 an amendment to the Companies Act introduced a legal requirement to comply with accounting standards approved by the Australian Accounting Review Board (Rahman, 1992). An "override" provision excused directors from this obligation if compliance would have meant that they were unable to give a true and fair view. In 1991 the law was amended so that:

"Where compliance would not in the directors' opinion give a "true and fair view" the directors are required to add such information as will give a "true and fair view" (Sadhan y Langfield-Smith, 1993, p.13).

In effect, after 1991, the "override" provision was no longer available to companies. That is, Australian companies can only use two tools to achieve a true and fair view: the meticulous compliance with accounting rules and the publication of additional financial information. In any case it is possible to "override" accounting legislation.

Deegan et al. (1994) explain this change: 
"The true and fair view override had been used by the directors of many companies as justification for not complying with particular accounting standards. As the meaning of true and fair is ambiguous, it is possible that some directors may have opportunistically invoked the override with the knowledge that it would be difficult for regulators to prove that the disclosure practices were not motivated by true and fair consideration" (p. 3).

This concern as to the ambiguity of the true and fair view requirement emerges repeatedly in the Australian literature. Thus Ryan (1974) observes:

"The phrase 'a true and fair view' whilst making a pleasant appeal to eye and ear is found, upon analysis, to be not only wholly inappropriate as a criterion for the verification of accounts but a snare and a delusion to the uninformed" (p. 8).

We have seen above that, in considering the definition of the 'true and fair view', a stock exchange committee proposed to sharpen up the term with a definition of the purpose and users of accounts. In support of that proposition it has been argued that:

"the amendments proposed may make it feasible to initiate prosecutions against those responsible for the publication of poor quality financial statements" (Kenley, 1985, p. 82).

This proposition was opposed by the professional accounting bodies on the grounds that:

"... to the extent that it widens the application of 'true and fair' it is inappropriate and impractical and would place an impossible responsibility on accountants, auditors, and directors" (Edwards, 1985, 6).

McGregor (1991, 416-7) reports that the Stock Exchange authorities in Australia deliberately held back from a prosecution for a flagrant breach of an accounting standard because of the ambiguity of "true and fair view" as a justification for compliance:

"I was advised that I could not win. It was also put that if we took a case and lost, 
the dam would burst and everybody would see that what we were saying could not be sustained in court. It seemed too risky to go down that road"

Thus overall the "True and Fair View" requirement in Australia appears to have worked in a "regressive way", as defined by Tweedie (1988), being used by companies to avoid the application of accounting standards.

\section{Impact of true and fair view in Spain}

According to Spanish accounting legislation, annual accounts must show a true and fair view of the net capital, the financial situation and the results of the company. The term true and fair view is the equivalent to the British concept of true and fair view, as it has been previously exposed the term is not clearly defined.

The British need that accounting rules emerge from the public criteria and the experience of accounting professionals rather than legislation imply that the British concept of true and fair view is in contradiction with Spanish accounting legislation and the Roman Law tradition. Túa (1985a) refers to "controversies whose origin is not other than differences between Continental and Anglo-Saxon Law" (p. 48).

In Spain, the assumption and application of true and fair view has been done without reservations. AECA in its Document number 1 from the Accounting Standards and Principles Commission states that:

"the Annual Accounts that companies have to present compulsorily, must contain suitable information for the adoption of decisions from the respective users. In other words, that the Annual Accounts give a true and fair view of the economic and financial situation of the company, of its income, expenditure and results, as well as the foreseen application of the results" (p. 15).

An illustration of the importance that for AECA has the requirement of true and fair view is that only these two words are highlighted in bold in the whole document, besides the headings to each section. The same Document indicates: 
"Both, fundamental and detailed accounting standards issued by AECA, have the objective of achieving a true and fair view" (p. 26).

The introduction of the Plan General de Contabilidad (Real Decree 1643/1990), in line with the Mercantile Code (article 38) and with the Texto Refundido de la Ley de Sociedades Anónimas, states:

"Although true and fair view is not a fixed or delimited concept, it tries to express the double notion of impartiality and objectivity that must be pursued when elaborating annual accounts.

True and fair view is the result of the systematic and regular application of accounting principles; considering accounting principles the mechanism able to express the economic reality of the transactions that have taken place.

To that end, the legal accounting dispositions or judicial requirement will not be applicable in particular transactions, if those were, exceptionally, incompatible with a true and fair view that annual accounts must present.

Therefore, the company must systematically adjust accounting and its annual accounts to the legal requirements that are applicable, except when conforming with these would lead to distorted annual accounts that a third party could believe to be a 'truthful', in economic terms, representation of the financial situation of the company.

The application of the accounting principles... must help to achieve a clear formulation of the annual accounts, expressing a true and fair view of the financial situation of the company and the profit and loss account".

The 1990 Plan also regulates some aspects to be included in the notes to the accounts regarding the application of true and fair view:

“a) True and fair view:

- Exceptional reasons for the non-application of legal accounting requirements in order to achieve a true and fair view and its effects on the assets, liabilities, financial position and profit or loss.

- Any additional information in the case that application of legal requirements is not 
enough to present a true and fair view.

The enforcement by which true and fair view has been imposed could lead to think that in Spain the concept is diaphanous. However, the existing confusion is in line with the disorientation at an international level. The following quotations from Spanish academics illustrate this point:

According to Túa $(1985$, b) "the fact that true and fair view is a philosophical concept and not susceptible of definition through a series of detailed rules is, in fact, the most fundamental and essential characteristic of the term" (p. 451).

A similar opinion is provided by Niño (1992):

"However, it is possible to think that the ultimate reason for not giving a definition, is that the term true and fair view is impossible to define" (p. 610).

Amongst Spanish two different approaches have been identified to the interpretation of true and fair view:

1. The legalist approach: according to these authors a true and fair view is achieved through the systematic application of current legislation. In this line Gondra (1991) states:

"It is clear. For our legislator there is no doubt the expression true and fair view is an objective term, stemming from the 'conformity with legal requirements', the true and fair view requirement tries to summarise the ultimate objective of the legal financial information system" (p. 579)

2. La economic approach: according to the opinion of this second group true and fair view is equivalent to economic reality or the adoption of a 'substance over form' philosophy. After the examination of articles written during the last two decades there is a clear indication that this approach seems to be the prevalent view amongst Spanish academics.

Gonzalo, Castro and Gabás (1985, p. 80) interpret the true and fair view concept as a 'substance over form' requirement and emphasise the usefulness of financial information for 
users. Similarly, Túa (1985, b) argues:

"the true and fair view principle implies firstly, compliance with the law, in a way that annual accounts must, in principle, be established according to legal requirements. Secondly, the annual accounts are required a "plus" to the true and fair view requirement through two additional directives that in European regulation complement this principle:

- with supplementary character, when the financial information legally required is not enough to present a faithful representation of the company's assets, liabilities and financial position, it is required to disclose more financial information.

- with priority character, the true and fair view requirement must prevail over any other norm or legal restriction, and in exceptional cases, the non-application of a legal requirement is allowed in order to achieve a true and fair view" (p. 442).

In the same sense, Vallverdú and Castillo (1991) state:

"Ultimately, the good accounting professional has the last word. It will be their professional responsibility and value judgements, helped with the experience and enough flexibility what will determine what is convenient in each case, challenging the use of the standards if adequate, which contrasts with the legalist objectivity previous to the reform. Therefore, the professional will decide whether or not to abandon the application of a standard with the aim to achieve the objective of annual accounts, that is providing annual accounts that show a true and fair view of the reality that they reflect" (p. 87).

From a theoretic point of view, it seems that in Spain there are two distinct opinions for the true and fair view requirement. However, the "economic" approach seems to prevail over the "legalistic" approach.

It is worth noting there is a difference between what the theory says and what are the accounting practices in the companies. Góxens (1990) indicates:

"Where is a true and fair view when the effects of inflation are not reflected in the 
balance sheet?.... In my modest opinion the persons responsible for the BOE must stop acting cynically and dictate the necessary measures so that balance sheets can reflect a true and fair view of the assets, liabilities, financial position and profit and loss, and not the prepared caricature according to the dispositions, more or less legal, that induce to deceitfulness" (p. 87).

Another criticism comes from Giner (1989) who states:

"Nevertheless, in our opinion, it is difficult to comply with both: the accounting principles, in particular the prudence principle, and the ultimate true and fair view objective (...) it seems that the balance sheet will not show a true and fair view of the assets and liabilities, assets will generally be valued at their acquisition value, or at the lowest market value, but other elements cannot appear in the balance sheet because they were rapidly amortised such as research and development and goodwill" (p. 422).

In another study, Giner (1991) insists that "it must be pointed out that currently, at least in our country, the opinion of Spanish auditors consists in indicating whether a true and fair view is represented according to the accounting standards generally accepted" (p. 12).

From the above quotations, it is observed that some accounting principles, mainly the principle of prudence and the principle of acquisition cost hinder that company accounts reflect the reality about the financial situation and assets and liabilities of the company. Without doubt, the most representative case is found in the accounting treatment for land and buildings, where in most cases, the acquisition cost is much lower than the real value.

This problem could be solved if in practice the possibility of the non-application of specific standards company was used with the objective to inform better about the company's financial reality. However, this possibility is only foreseen in exceptional cases and the problem of accounting under valuation of land and buildings affects most companies.

Ernst \& Young (1995) conducted a study on 150 big Spanish companies. In the notes to the accounts, all of them had stated that their annual accounts presented a true and fair view, interestingly there was no indication as to whether they had used the true and fair view 
override in order to achieve it. In a similar project, Navarro (1995) using a sample of 74 companies, it was found that only two of them had used the override and the auditor's reports were favourable in respect of the decision to use the override. Another study of 342 companies through the EC (Fédération des Experts Comptables, 1991) identifies only 10 cases of companies using the true and fair view override. Although consenting with the economic approach to true and fair view, it seems that in Spanish practice true and fair view is interpreted under a legalistic approach.

Thus, in its actual form, it can be deduced that the concept of true and fair view is losing its opportunity to combat the problem of creative accounting. To solve this problem some reform should be introduced. For example, the interpretation of true and fair view as 'substance over form' would diminish the occasions in which creative accounting can be applied. Other measures would include the reduction of accounting choices allowed and the development of an ethical code for the accounting profession.

\section{Conclusion}

There is an increased awareness of the problem of creative accounting in Spain, as evidenced by articles in accounting and business journals. This poses a major threat to the accounting profession, in terms of their credibility and standing in the business community. It also creates major problems of litigation risk for auditors. If the government and the accounting profession in Spain work together then the concept of true and fair view can be a key part of the solution to this problem. To achieve this it is necessary that:

a) There is a reduction on the range of accounting choices allowed for the same economic transaction and therefore, reducing the opportunities of creative accounting in the field of choice of accounting method.

b) To reduce the opportunities of creative accounting as a consequence of estimates and predictions, accounting regulation should reduce the area allowed for subjective evaluations.

c) To reduce the opportunities of creative accounting as a consequence of artificial transactions, accounting regulation should encourage the interpretation of true and fair view as the prevalence of substance over form.

d) That the legislators recognise the institutions of the accounting community as the source 
of guidance on what accounting practices constitute true and fair view.

e) The accounting profession also needs to strengthen its ethical code so that the individual accountant or auditor is less willing to connive at creative accounting.

By contrast, if no action is taken true and fair view will enhance the problem of creative accounting because:

a) It relaxes the traditional rigidity of accounting regulation and so increases the opportunity for accounting policy choice.

b) It empowers companies to claim the right to use their own discretion in accounting policy choice rather than accepting the authority of the professional accounting bodies.

Thus the choice of how to interpret and apply the concept of true and fair view may be seen as crucial for the future credibility of the Spanish accounting profession. 


\section{References}

Accounting Standards Board (1993) "Foreword to Accounting Standards" Accountancy, July.

Accounting Standards Board (1995) "Goodwill and intangible assets: working paper for discussion at public hearing" Accounting Standards Board, London.

Alexander, D. (1993) "A European imagen fiel?" European Accounting Review, May, pp. 5980.

Amat Salas, O. and Blake, J. (1996) "Contabilidad Creativa" Gestión 2000, Barcelona.

Benson, H. (1989) "Accounting for life" Kogan Page, London.

García Benau, M.A. and Humphrey, C. (1995) "La auditoría y el fraude: algunas consideraciones internacionales" Revista Española de Financiación y Contabilidad, Vol. XXIV, No. 84, pp. 697-726.

Blake, J. and Higson, A. (1992) "A consideration of the significance and value of the 'neutrality' concept in Financial Accounting” Accounting Forum, September, pp. 4-32.

Burlaud, A. (1993) "Commentaires sur l'article de David Alexander `A European imagen fiel'?" European Accounting Review, May, pp. 95-98.

Busse von Colbe, W. (1984) "A imagen fiel: A German perspective" incluído en el libro "EEC accounting harmonisation: implementation and impact of the fourth directive" Gray, S.J. and Coenenberg, A.G. (eds) North Holland, pp. 121-128.

Cañibano Calvo, L. (1992) "Regulación profesional: principios contables AECA" in Contabilidad en España edited by Gonzalo Angulo, J.A., ICAC, Ministerio de Economía y Hacienda, Madrid, pp. 109-128.

Cowan, T.K. (1965) "Are truth and fairness generally acceptable?" Accounting Review, October, pp. 188-194. 
Deegan, C., Kent, P. y Lin, C.J. (1994) "The imagen fiel: a study of Australian auditors'application of the concept" Australian Accounting Review, Vol. 4, No. 1, pp. 2-12.

Edwards, B. (1985) "'Imagen fiel' - not just an academic debate" The Chartered Accountant in Australia, March, pp. 6.

Ernst \& Young (1995) "Soluciones prácticas para la elaboración de cuentas anuales" Cinco Días, Madrid.

Fédération des Experts Comptables Européens (1991) "FEE European Survey of Published Accounts 1991" Routledge, Londres.

Gabás Trigo, F. (1991) "El marco conceptual de la contabilidad financiera" Monografías 17, AECA, Madrid.

Gibson, R.W. (1971) "Disclosure by Australian companies" University Press, Melbourne.

Giner Inchausti, B. (1989) "Características y objetivos de la reforma contable española" Técnica Contable, pp. 417-428.

Giner Inchausti, B. (1991) "De los principios contables generalmente aceptados a los legalmente establecidos" Técnica Contable, March, 507, pp.125-138.

Gondra, J.M: (1991) "Significado y función del principio de "Imagen Fiel"" ("True and fiar view") en el sistema del nuevo Derecho de Balances", in Derecho Mercantil de la Comunidad Económica Europea Estudio en homenaje a José Girón Tena, Madrid, p. 579.

Gonzalo, J.A., Castro, E. y Gabás, F. (1985) "Los principios contables fundamentales en la actualidad" VII Congreso de Censores Jurados de Cuentas de España, March, Vigo, p. 80.

Góxens, A. (1990) "Inflación e imagen fiel del patrimonio" Técnica Contable, April, pp. 169170 and 178. 
Gray, S.J. and Coenenberg, A.G. (1984) (eds) "EEC accounting harmonisation: implementation and impact of the Fourth Directive" North Holland.

Griffiths, I. (1986) “Creative accounting” Sidgwick \& Jackson, London.

Kenley, J. (1985) "More from Australia on Imagen fiel" The Accountants Magazine, February, pp. 82-83.

Hoffman, L. and Arden, M.H. (1983) "The Accounting Standards Committee Joint Opinion" Accountancy, November, pp. 154-156.

Jameson, M. (1988) “A practical guide to creative accounting” Kogan Page, London.

Lee, G.A. (1981) "Modern financial accounting" Nelson, Walton on Thames, Surrey.

Leung, P and Cooper, B.J. (1995) "Ethical dilemmas in accountancy practice" Australian Accountant, May, pp. 28-33.

McGregor, W. (1991) "Imagen fiel - an accounting anachronism" Company and Securities Law Journal, December.

Mayson, S.W., French, D. and Ryan, C.L. (1989) "Company Law" Blackstone Press, London.

NCSC (1984) "A imagen fiel and the reporting obligations of directors and auditors" The Australian Government Publishing Service, Canberra.

Naser, K. (1993) “Creative Financial Accounting: its nature and use” Prentice Hall, London.

Navarro Gomollón, A.J. (1996) "Principios contables fundamentales" Técnica Contable, 567, March, pp. 153-168.

Niño, M. (1992) "El principio de prudencia y la imagen fiel: un breve comentario" Técnica Contable, 526, October, pp. 609-618. 
Nobes, C.W. (1993) "The imagen fiel requirement: impact on and of the Fourth Directive" Accounting Business Research, Vol. 24, No. 93, pp. 35-48.

Ordelheide, D. (1993) "Imagen fiel: a European and a German perspective. A commentary on 'A European imagen fiel?' by David Alexander" European Accounting Review, May, pp. 8190 .

Rahman, A. (1992) "The Australian Accounting Standards Review Board: the establishment of its participative review process" Garland, New York.

Rojo, L..A. (1993) "Tendencias de contabilidad y contabilidad creativa" Boletín AECA, n. 36, pp. 4-7.

Rutherford, B.A. (1983) "Spoilt beauty: the imagen fiel doctrine in translation" AUTA Review, Spring, pp. 33-36.

Ryan, F.J.O. (1967) "A imagen fiel" Abacus, October, pp. 95-108.

Ryan, F.J.O. (1974) "A imagen fiel revisited" The Australian Accountant, February, pp. 8-16.

Sadhan, M.A. and Langfield-Smith, I.A. (1993) "A qualitative standard for general purpose and financial reports: a review" Australian Accounting Research Foundation, Caulfield.

Smith, T. (1992) “Accounting for growth” Century Business, Londres.

Túa Pereda, J. (1985,a) "Los principios contables de la regulación profesional al ámbito internacional" Revista Española de Financiación y Contabilidad, January-April, pp. 25-86.

Túa Pereda, J. (1985,b) "Algunas precisiones adicionales en torno al principio de imagen fiel" Técnica Contable, December, pp. 441-484.

Tweedie, D. (1983) "The ASB in chains: whither self-regulation now? Accountancy, March, pp. 112-120. 
Tweedie, D. (1988) "Imagen fiel v. the rule book: which is the answer to creative accounting" Pacific Accounting Review, December, pp. 1-21.

Vallverdú, J. and Castillo, F.J. (1991) "De las directivas de la CEE al Plan General de Contabilidad 1990" Einia.

Waller, D. (1990) "Time to get rid of imagen fiel?" Accountants Magazine, December, pp. 53.

Williams, D.N. (1985) "Legal perspectives on auditing" included in "Current Issues in Auditing" Kent, D., Sherer, M., Turley, S. (eds) Harper and Row, pp. 15-32.

Zeff, S. (1972) "Forging Accounting Principles in Five Countries: a history and an analysis of trends" Stiples Publishing Company, Illinois. 